\title{
Bacteriological Quality and Risk Factors for Contamination of Raw Mixed Vegetable Salads Served in Collective Catering in Abidjan (Ivory Coast)
}

\author{
Evelyne Toe'1, Adjéhi Dadié1, Etienne Dako2* ${ }^{*}$, Guillaume Loukou ${ }^{3}$ \\ ${ }^{1}$ Laboratory of Nutrition and Food Safety, Department of Food Science and Technology, University of Nanguy Abrogoua, \\ Abidjan, Ivory Coast \\ ${ }^{2}$ Laboratory of Biotechnology and Molecular Biology, School of Food Science, Nutrition and Family Studies, Faculty of Health \\ Science and Community Services, University of Moncton, New-Brunswick, Canada \\ ${ }^{3}$ Laboratoire Nationale de la Santé Publique (LNSP), Abidjan, Ivory Coast \\ Email: *etienne.dako@umoncton.ca
}

How to cite this paper: Toe, E., Dadié, A. Dako, E. and Loukou, G. (2017) Bacteriological Quality and Risk Factors for Contamination of Raw Mixed Vegetable Salads Served in Collective Catering in Abidjan (Ivory Coast). Advances in Microbiology, 7, 405-419.

https://doi.org/10.4236/aim.2017.76033

Received: April 2, 2017

Accepted: June 6, 2017

Published: June 9, 2017

Copyright $\odot 2017$ by authors and Scientific Research Publishing Inc. This work is licensed under the Creative Commons Attribution International License (CC BY 4.0).

http://creativecommons.org/licenses/by/4.0/

\section{c) (i) Open Access}

\begin{abstract}
The aim of this study was to determine the bacteriological quality of raw mixed vegetable salads served in collective catering in Abidjan and to assess the factors likely to favor contamination. An investigation was conducted to determine the practical risk of contamination. A total of 306 samples were collected and analyzed for the detection and enumeration of Enterobacteriaceae, E. coli and Salmonella according to standard microbiology methods. The most important risk factors were lack of training (96.7\%), decontamination (84.0\%), cross-contamination of vegetables in contact with fresh chicken or fish (76.7\%) and salads that were uncovered and unprotected, thus exposed to the air and at ambient temperature for sale (97.7\%). Theprevalence was $100 \%$, $77.8 \%$ and $2.6 \%$ respectively for Enterobacteriaceae, E. coli and Salmonella. The average load of Enterobacteriaceae and E. coli was $4.93 \log _{10}(\mathrm{CFU} / \mathrm{g})$ and $1.89 \log _{10}$ (CFU/g), respectively. Unsatisfactory microbiological quality samples were $52.3 \%$. The results showed a failure of the sanitary quality in more than half of the products. Raising awareness in all of the workers in the food chain for vegetable salads is thus necessary to protect the health of the consumers.
\end{abstract}

\section{Keywords}

Vegetable Salads, E. coli, Salmonella, Risk Factors, Collective Catering

\section{Introduction}

Fruits and vegetables are an essential part of the human diet. A diet rich in fruits 
and vegetables reduces the risk of obesity, cancers and cardiovascular diseases that are considered to be the leading causes of death and disability in the world [1] [2]). Thus, World Health Organization (WHO), European Food Safety Authority (EFSA), Food \& Agriculture Organization (FAO) and French Agency for Food Safety (AFSSA) recommend and encourage consumption of at least five servings of fruits and vegetables per day [2]. Despite the benefits that are associated with consumption of fruits and vegetables, food security of those consumed fresh remains a major concern, because these foods are considered as vectors of infectious disease transmission [3].

Over past decade, the number of cases of foodborne illness associated with fresh fruits and vegetables in developed countries has increased. Among the pathogens, pathogenic E. coli and Salmonella are most often involved [4] [5] [6] [7]. From May to June 2011, two separate outbreaks of bloody diarrhea and hemolytic uremic syndrome (HUS) occurred in Europe and both were caused by shiga toxin producing a strain (STEC) O104:H4. An outbreak centered in Germany included 845 cases of HUS and 54 deaths; the other outbreak, centered in France, included only nine cases of HUS [6] [8]. This was one of the largest outbreaks of poisoning in Shiga Toxin E. coli (STEC) associated with vegetables, and was never reported. In developing countries, foodborne illnesses caused by contaminated fruits and vegetables are common and, in some areas, they cause a high proportion of diseases; however, due to the lack of investigation and monitoring of foodborne diseases in most of these countries, a very high proportion of outbreaks are not detected, or very few are mentioned in scientific reports [3]. Vegetable contamination can occur at any time in the food chain, from the farms to the consumer's plate, through transportation, distribution and markets, with the presence or absence of pathogens [9]. In developing countries, many risk factors are considered the main contamination factors, such as improperly composted manure, untreated wastewater used for irrigation, poor post-harvest handling, especially in markets, and unhygienic food handling practices [10] [11] [12].

In Côte d'Ivoire, raw mixed vegetable salads are generally made of raw tomatoes, onions, cucumbers and/or lettuce that have been washed, peeled, cut, seasoned or unseasoned and ready to use. They are used in catering as a garnish or accompaniment to many meals. Studies have shown that vegetables are subjected to various sources of microbial contamination before and after harvesting, during transport and at places of sale in Abidjan [13] [14] [15]. Microorganisms, mainly enteric bacteria with pathogenic potentialities, including Salmonella and E. coli, were isolated from vegetables harvested in fields and sold in markets [14]. There is a lack of data available on the microbiological quality of lettuce in the fields and markets; there is none for raw mixed vegetable salads served in catering. Furthermore, there is a lack of data on key risk factors for contamination of salads.

The aim of this study is to assess the bacteriological quality and to determine risk factors for contamination with enteric bacteria including E. coli and Salmo- 
nella in raw mixed vegetable salads served in catering to Abidjan.

\section{Materials and Methods}

\subsection{Study Areas}

The study was conducted in the district of Abidjan, the economic capital of Côte d'Ivoire. The district is located in the south, bordering the Atlantic Ocean (Gulf of Guinea), covering an area of $2119 \mathrm{~km}^{2}$ ( $0.6 \%$ of the country) with a population density of 1475 inhabitants $/ \mathrm{km}^{2}$. According to the Institut National de la Statistique de Côte d Ivoire (INS), the district of Abidjan has an estimated population of 4,707,000 inhabitants; representing $20.7 \%$ of the total population and a growth rate of $3.7 \%$ per year [16]. Abidjan is a large area of agricultural production, especially of vegetables, and where one meets different sites of restoration. The city comprises 13 municipalities, including five where this study was conducted. Figure 1 shows a map of the city with the study sites indicated.

\subsection{Investigation}

A survey based on questionnaires and direct observation was conducted from March to November 2015 among 150 vendors of raw vegetable salads that were used as an accompaniment to main meal in catering in Abidjan. To validate this questionnaire, a focus group of five randomly selected individuals was constituted. Sociodemographic characteristics (age, nationality, education level, years of experience, catering training) and risk factors that could cause contamination of vegetables were determined. These included: conditions for the preservation of vegetables in the restaurant, methods and products used for washing and decontamination of vegetables, utensils used for cutting and dressing and the possibility of cross-contamination with fresh meat products (meat, poultry, fish).

\subsection{Sampling of Raw Mixed Vegetables Salads}

A total of 306 samples of raw mixed vegetable salads, consisting of tomatoes, onions, cucumbers and/or lettuce, seasoned or unseasoned, were collected for analysis. In each restaurant, two samples of about 100 to $200 \mathrm{~g}$ were collected at two-week intervals. Samples were collected between $7 \mathrm{am}$ and $5 \mathrm{pm}$ and between $6 \mathrm{pm}$ and $11 \mathrm{pm}$, depending on the main course that accompanied the salad. A file was attached to each sample for information on the type of vegetables added in the salad preparation, the time of sampling (day or night) and the sampling commune (Abobo, Adjamé, Yopougon, Treichville, Cocody). After collection, the samples were transported to the laboratory in a cooler containing Ice-Pack.

\subsection{Analysis of Samples}

From each sample previously ground in a Stomatcher (Seward Limited, England), 25 grams were weighed aseptically and added to $225 \mathrm{ml}$ buffered peptone water (Bio-rad, France) for the preparation of initial suspensions. Serial dilutions (10-1 to 10-5) were carried out in tryptone salt (Biorad, France). Initial suspensions and dilutions were used for the culture and enumeration of Enterobacte- 


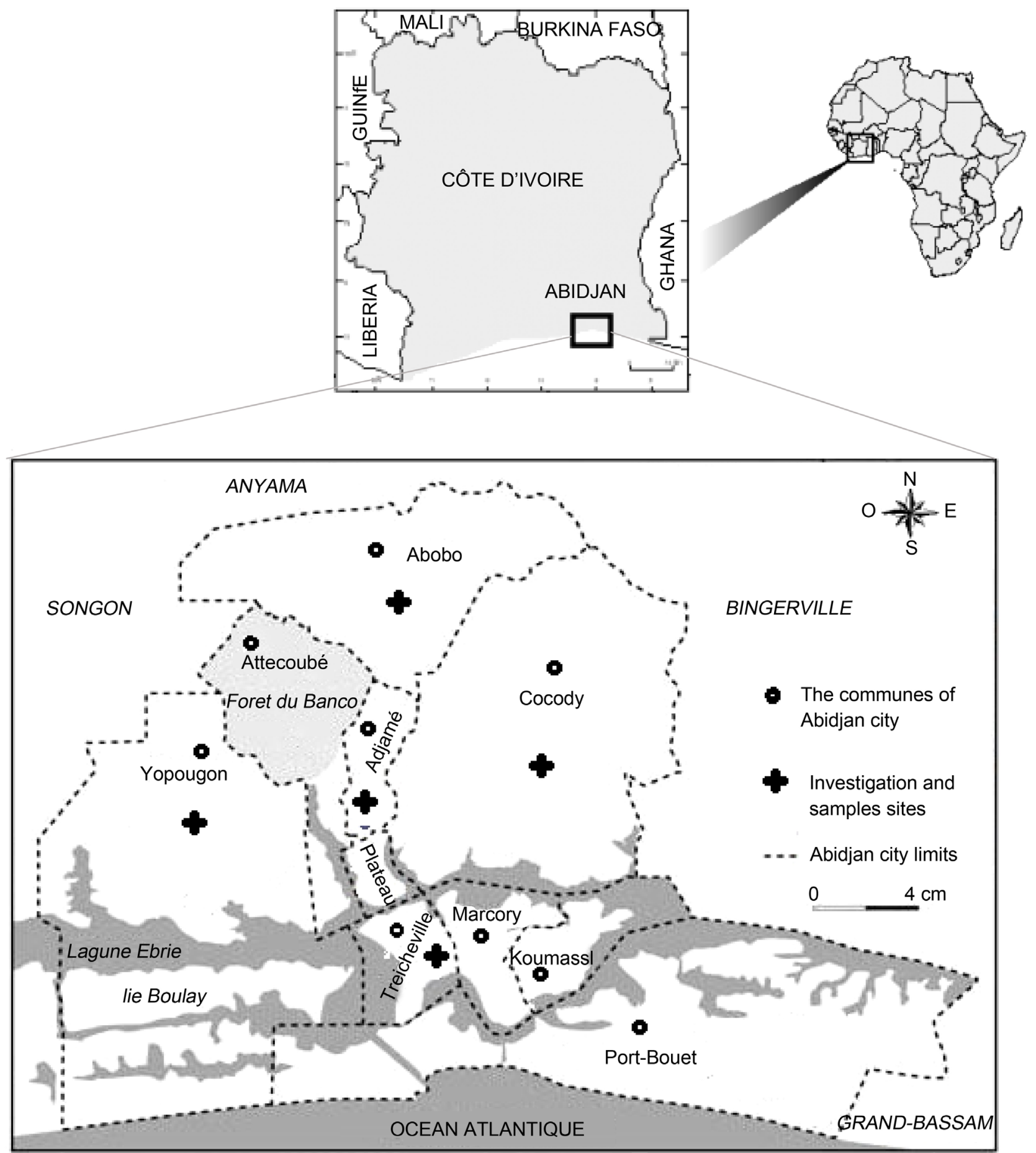

Figure 1. Map of Abidjan with the study sites indicated.

riaceae, E. coli, and the search for salmonella, in order to investigate two factors, including bacterial loads and non-selective pre-enrichment in the case of Salmonella.

\subsubsection{Enumeration of Enterobacteriaceae}

Enumeration of Enterobacteriaceae was made according to ISO 21528-2:2004. A culture was performed on agar VRBG (Violet Red Bile Glucose Agar) (Bio-Rad, 
France). After incubation at $37^{\circ} \mathrm{C}$ for 24 hours, the characteristic red violet colonies with a diameter of $0.5 \mathrm{~mm}$ or more, sometimes surrounded by a reddish zone, were counted.

\subsubsection{Enumeration of $E$. coli}

The enumeration of $E$. coli was performed on selective chromogenic medium RAPID' E. coli 2 (Bio-Rad, France), according to ISO 16140. After incubation at $44^{\circ} \mathrm{C}$ for 24 hours, colonies of $E$. coli, which are purple to pink due to the presence of $\beta$-D-glucuronidase (GLUC) and $\beta$-D-galactosidase (GAL), were counted.

\subsubsection{Detection of Salmonella}

The detection of Salmonella was carried out according to standard NF EN ISO 6579: 2002. Each initial suspension was incubated at $37^{\circ} \mathrm{C}$ for 18 hours for pre-enrichment. After incubation, $0.1 \mathrm{ml}$ of this suspension was added to $10 \mathrm{ml}$ of RVS broth (Bio-rad, France); in parallel, a series of two drops was deposited at the center of two petri dishes containing a Medium Semisolid Rappaport Vassiliadis (MSRV) supplemented with novobiocin $20 \mathrm{mg} / \mathrm{l}$ (Lyofilichen, France). The RVS and MSRV broths (Bio-rad, France) were incubated at $42^{\circ} \mathrm{C}$. for 24 hours for the first, and 24 to 48 hours for the second. Both media were then seeded on Hektoen (Bio-rad, France) and Salmonella-Shigella (SS) agar plates and incubated at $37^{\circ} \mathrm{C}$. for 24 hours. On SS agar, Salmonella have colorless and transparent colonies (due to lactose fermentation), with or without a black center $\left(\mathrm{H}_{2} \mathrm{~S}\right.$ production) and on Hektoen, from blue to green colonies with or without a black center. Five characteristic colonies on each plate were streaked on nutrient agar for biochemical identification. Biochemical identification was performed using an API 20E gallery.

\subsection{Statistical Analysis and Interpretations of Results}

The results of the surveys were coded and entered in Microsoft Excel version 2013 and transferred to IBM SPSS VERSION 20. Descriptive statistics (frequency, mean, standard deviation) were used for the quantitative variables. Data on socio-demographic characteristics (age, sex, nationality, religion, level of education, experience) and data on microbiological analysis (frequency, average loads, compliance) were analyzed for variance (Anova), with a factor to determine the relationship between dependent and independent (common) variables. A posthoc comparison test with Bonferroni was performed when there were differences between the variables. The differences between the variables were considered significant at $p<0.05$. All statistical analyzes were performed using SPSS statistical program for Windows version 20. For the enumeration, the boxes containing less than 150 colonies and medium loads were taken into account and have been reported according to ISO 7218_2007, and then transformed into $\log _{10}$ CFU/ g. The standard used by the French Association of Standardization (AFNOR), which indicates a limit of $10^{2} \mathrm{CFU} / \mathrm{g}\left(2 \log _{10} \mathrm{CFU} / \mathrm{g}\right)$ for $E$. coli for ready-to-eat foods, and the absence in $25 \mathrm{~g}$ in the case of Salmonella. The use of these limits made it possible to assess the microbiological quality and/or the conformity of 
the samples analyzed.

\section{Results}

\subsection{Sociodemographic Characteristics}

Sociodemographic characteristics have been analyzed to highlight the impact of the following factors: education level and the training in catering on food microbiological quality. In catering, where raw mixed vegetable salads are used, accompanied by the main course, all interviewed sellers were only women vendors, whose ages varied between 30 and 45 years, and represented 54\%.The vast majority never followed catering training $(96.7 \%)$, and had been practicing this activity for more than five years (40.7\%). Of these women, $31.3 \%$ had a primary education level and $41.3 \%$ had never attended school. From one commune to another, sociodemographic characteristics did not vary significantly $(P>0.05)$ outside age, level of study and number of years of experience $(P<0.05)$ (Table 1$)$.

\subsection{Factors and Practices at Risk of Contamination}

After buying at the market, $96.3 \%$ of salespeople store vegetables at the point of sale and $72.5 \%$ at room temperature without protection. During the conservation, vegetables come into contact with food of animal origin in $23.3 \%$ of cases. Before cutting up the vegetables, sellers say they do not wash (1.3\%) and disinfect them (84\%). At the point of sale, $22 \%$ say they do not change the rinse water

Table 1. Sociodemographic characteristics of vegetable salad vendors.

\begin{tabular}{|c|c|c|c|c|c|c|c|}
\hline \multirow[b]{2}{*}{ Parameters } & \multirow[b]{2}{*}{ Responses } & \multicolumn{5}{|c|}{ Respondents (\%) } & \multirow{2}{*}{$\begin{array}{c}\text { Total } \\
\mathrm{N}:\end{array}$} \\
\hline & & $\begin{array}{c}\text { Adjamé } \\
\mathrm{N}: 30\end{array}$ & $\begin{array}{c}\text { Abobo } \\
\mathrm{N}: 30\end{array}$ & $\begin{array}{l}\text { Yop } \\
\text { N:30 }\end{array}$ & $\begin{array}{c}\text { Cocody } \\
\mathrm{N}: 30\end{array}$ & $\begin{array}{l}\text { Treic } \\
\mathrm{N}: 30\end{array}$ & \\
\hline \multirow{2}{*}{ Sex } & Man & $0 \mathrm{a}$ & $0 \mathrm{a}$ & $0 \mathrm{a}$ & $0 \mathrm{a}$ & $0 \mathrm{a}$ & 0.0 \\
\hline & Woman & $100 \mathrm{a}$ & $100 \mathrm{a}$ & $100 \mathrm{a}$ & $100 \mathrm{a}$ & $100 \mathrm{a}$ & 100.0 \\
\hline \multirow{2}{*}{ Origin } & Ivorian & $90.0 \mathrm{a}$ & $86.7 \mathrm{a}$ & $83.3 \mathrm{a}$ & $80.0 \mathrm{a}$ & $93.3 \mathrm{a}$ & $86.7 \mathrm{a}$ \\
\hline & Not Ivorian & $10.0 \mathrm{a}$ & $13.3 \mathrm{a}$ & $16.7 \mathrm{a}$ & $20.0 \mathrm{a}$ & $6.7 \mathrm{a}$ & $13,3 \mathrm{a}$ \\
\hline \multirow{3}{*}{ Age } & Under 30 years & $43.3 \mathrm{a}$ & $43.3 \mathrm{ab}$ & $33.3 \mathrm{a}$ & $16.7 \mathrm{ab}$ & $10.0 \mathrm{~b}$ & 29.3 \\
\hline & $30-45$ years & $46.7 \mathrm{a}$ & $50.0 \mathrm{a}$ & $63.3 \mathrm{a}$ & $43.3 \mathrm{a}$ & $66.7 b$ & 54.0 \\
\hline & Over 45 years & $10.0 \mathrm{abcd}$ & $6.7 \mathrm{bd}$ & $3.3 \mathrm{~cd}$ & $40.0 \mathrm{a}$ & 23.3abcd & 16.7 \\
\hline \multirow{4}{*}{ Studylevel } & Not in school & $56.7 \mathrm{a}$ & $40.0 \mathrm{a}$ & $33.3 \mathrm{a}$ & $36.7 \mathrm{a}$ & $40.0 \mathrm{a}$ & $41.3 \mathrm{~b}$ \\
\hline & Primaryschool & $26.7 \mathrm{a}$ & $36.7 \mathrm{a}$ & $23.3 \mathrm{a}$ & $26.7 \mathrm{a}$ & $43.3 \mathrm{a}$ & $31.3 \mathrm{c}$ \\
\hline & Secondaryschool & $16.7 \mathrm{a}$ & $13.3 \mathrm{a}$ & $40.0 \mathrm{a}$ & $26.7 \mathrm{a}$ & $13.3 \mathrm{a}$ & 22.0 \\
\hline & High school & $0.0 \mathrm{a}$ & $10.0 \mathrm{a}$ & $3.3 \mathrm{a}$ & $10.0 \mathrm{a}$ & $3.3 \mathrm{a}$ & 5.3 \\
\hline \multirow{2}{*}{$\begin{array}{c}\text { Training in } \\
\text { catering }\end{array}$} & No & $100 \mathrm{a}$ & $93.3 \mathrm{a}$ & $100 \mathrm{a}$ & $93.7 \mathrm{a}$ & $96.7 \mathrm{a}$ & 96.7 \\
\hline & Yes & $0.0 \mathrm{a}$ & $6.7 \mathrm{a}$ & $0.0 \mathrm{a}$ & $6.7 \mathrm{a}$ & $3.3 \mathrm{a}$ & 3.3 \\
\hline \multirow{3}{*}{$\begin{array}{c}\text { Years of } \\
\text { experience }\end{array}$} & Under 5 years & $50.0 \mathrm{a}$ & $50.0 \mathrm{a}$ & $40.0 \mathrm{a}$ & $23.3 \mathrm{a}$ & $40.0 \mathrm{a}$ & $40.7 \mathrm{a}$ \\
\hline & $5-15$ years & $40.0 \mathrm{a}$ & $33.3 \mathrm{a}$ & $46.7 \mathrm{a}$ & $50.0 \mathrm{a}$ & $16.7 \mathrm{a}$ & $37.3 \mathrm{~b}$ \\
\hline & Over 15 years & $10.0 \mathrm{a}$ & $16.7 \mathrm{ab}$ & $13.3 \mathrm{ab}$ & $26.7 \mathrm{ab}$ & $43.3 \mathrm{~b}$ & 22.0 \\
\hline
\end{tabular}

Note: Means with the same letter in the same column are not significantly different $(P<0.05)$. Commun Yop (Yopougon) and Treich (Treicheville). 
during the cutting and $38.7 \%$ say they entrust the cutting up of the vegetables to the younger girls. Vegetables are cut up and progressively used during the hours of sale in $64.4 \%$ of the cases and stored at room temperature in $97.7 \%$ of the cases. The utensils used to cut vegetables are also used to cut chicken or fresh fish (37.7\%). Special containers are used for seasoning the vegetables cut in most cases $(79.3 \%)$ and are not cleaned during sale in $47.8 \%$ of cases (Table 2 ).

\subsection{Prevalence of Bacteria in Vegetable Salad Samples}

The prevalences of bacteria in the analyzed samples are presented in Table 3. The prevalences are 100\%, $77.8 \%$ and $2.6 \%$ respectively for Enterobacteriaceae, E. coli and Salmonella and are significantly different $(P<0.05)$. Prevalences of $E$.

Table 2. Sales conditions and practices.

\begin{tabular}{|c|c|c|c|c|c|c|c|}
\hline \multirow{2}{*}{ Parameters } & \multirow{2}{*}{ Responses } & \multicolumn{5}{|c|}{ Respondents (\%) } & \multirow{2}{*}{ Tota } \\
\hline & & Adj & Abobo & Yop & Cocody & Treich & \\
\hline \multirow{2}{*}{$\begin{array}{c}\text { Methods of preserving } \\
\text { vegetables }\end{array}$} & Refrigerator & $3.3 \mathrm{a}$ & $0.0 \mathrm{a}$ & $3.3 \mathrm{a}$ & $10 \mathrm{a}$ & $0.0 \mathrm{a}$ & 3.3 \\
\hline & ambiant $\mathrm{T}$ & $96.7 \mathrm{a}$ & $100 \mathrm{a}$ & $96.7 \mathrm{a}$ & $90.0 \mathrm{~b}$ & $100 \mathrm{a}$ & 96.7 \\
\hline \multirow{2}{*}{$\begin{array}{l}\text { Protection vegetables at } \\
\text { room temperature }\end{array}$} & No & $70.0 \mathrm{a}$ & $58.6 \mathrm{a}$ & $80.0 \mathrm{a}$ & $76.7 \mathrm{a}$ & $76.7 \mathrm{a}$ & $72.5 \mathrm{a}$ \\
\hline & Yes & $30.0 \mathrm{a}$ & 41.4 & $20.0 \mathrm{a}$ & $23.3 \mathrm{a}$ & $23.3 \mathrm{a}$ & $27.5 \mathrm{a}$ \\
\hline \multirow{2}{*}{$\begin{array}{l}\text { Contact with chicken or fish } \\
\text { in storage }\end{array}$} & No & $86.7 \mathrm{a}$ & $80.0 \mathrm{a}$ & $40.0 \mathrm{~b}$ & $83.3 \mathrm{a}$ & $93.3 \mathrm{a}$ & 76.7 \\
\hline & Yes & $13.3 \mathrm{a}$ & $20.0 \mathrm{a}$ & $60.0 \mathrm{~b}$ & $16.7 \mathrm{a}$ & $6.7 \mathrm{a}$ & 23.3 \\
\hline \multirow{2}{*}{ Washed before cutting } & No & $3.3 \mathrm{a}$ & $0 \mathrm{a}$ & $3.3 \mathrm{a}$ & $0 \mathrm{a}$ & $0 \mathrm{a}$ & 98.7 \\
\hline & Yes & $96.7 \mathrm{a}$ & $100 \mathrm{a}$ & $96.7 \mathrm{a}$ & $100 \mathrm{a}$ & $100 \mathrm{a}$ & 1.3 \\
\hline \multirow{2}{*}{$\begin{array}{c}\text { Disinfection of } \\
\text { vegetables before cutting }\end{array}$} & No & $86.7 \mathrm{a}$ & $90.0 \mathrm{a}$ & $86.7 \mathrm{a}$ & $66.7 \mathrm{a}$ & $90.0 \mathrm{a}$ & $84.0 \mathrm{a}$ \\
\hline & Yes & $13.3 \mathrm{a}$ & $10.0 \mathrm{a}$ & $13.3 \mathrm{a}$ & $33.3 \mathrm{a}$ & $10.0 \mathrm{a}$ & 16.0 \\
\hline \multirow{2}{*}{$\begin{array}{l}\text { Change of the rinse } \\
\text { water during the cutting }\end{array}$} & No & $40.0 \mathrm{a}$ & $6.7 \mathrm{~b}$ & $3.3 \mathrm{~b}$ & $16.7 \mathrm{ab}$ & $43.3 \mathrm{a}$ & 22.0 \\
\hline & Yes & $60.0 \mathrm{a}$ & $93.3 \mathrm{~b}$ & $96.7 \mathrm{a}$ & $83.3 \mathrm{ab}$ & $56.7 \mathrm{a}$ & 78.0 \\
\hline \multirow{2}{*}{$\begin{array}{l}\text { Personnel responsible for } \\
\text { cutting vegetables }\end{array}$} & Vendors & $36.7 \mathrm{a}$ & $73.3 \mathrm{~b}$ & $60.0 \mathrm{ab}$ & $66.7 \mathrm{ab}$ & $70.0 \mathrm{ab}$ & 61.3 \\
\hline & Young Girls & $63.3 \mathrm{a}$ & $26.7 \mathrm{~b}$ & $40.0 \mathrm{ab}$ & $33.3 \mathrm{ab}$ & $30.0 \mathrm{ab}$ & 38.7 \\
\hline \multirow{2}{*}{$\begin{array}{l}\text { Immediate use of cut } \\
\text { vegetables }\end{array}$} & Yes & $6.7 \mathrm{a}$ & $66.7 \mathrm{c}$ & $20.0 \mathrm{ab}$ & $40.0 \mathrm{bc}$ & $46.7 \mathrm{bc}$ & 36.0 \\
\hline & No & $93.3 \mathrm{a}$ & $33.3 \mathrm{c}$ & $80.0 \mathrm{ab}$ & $60.0 \mathrm{bc}$ & $53.3 \mathrm{c}$ & 64.0 \\
\hline \multirow{2}{*}{ Mode of salads conservation } & Refrigerator & $0 \mathrm{a}$ & $0 \mathrm{a}$ & $0 \mathrm{a}$ & 8.3 & $0 \mathrm{a}$ & 2.3 \\
\hline & Ambient $\mathrm{T}$ & $100 \mathrm{a}$ & $100 \mathrm{a}$ & $100 \mathrm{a}$ & 91.7 & $100 \mathrm{a}$ & 97.7 \\
\hline \multirow{2}{*}{$\begin{array}{l}\text { Using the same utensil for } \\
\text { cutting vegetables, chicken } \\
\text { or fresh fish }\end{array}$} & No & $20.0 \mathrm{ab}$ & $53.3 \mathrm{ac}$ & $10.0 \mathrm{~b}$ & $40.0 \mathrm{abc}$ & $63.3 \mathrm{c}$ & 37.3 \\
\hline & Yes & $80.0 \mathrm{ab}$ & $46.7 \mathrm{ac}$ & $90.0 \mathrm{~b}$ & $60.0 \mathrm{abc}$ & $36.7 \mathrm{c}$ & 62.7 \\
\hline \multirow{3}{*}{$\begin{array}{l}\text { Washing the container } \\
\text { during the sale }\end{array}$} & No & $94.4 \mathrm{a}$ & $14.8 \mathrm{~b}$ & $25.9 \mathrm{~b}$ & $46.7 \mathrm{~b}$ & $100 \mathrm{a}$ & 47.8 \\
\hline & Yes & $5.6 \mathrm{a}$ & $85.2 \mathrm{~b}$ & $74.1 \mathrm{~b}$ & $53.3 \mathrm{~b}$ & 0a & 52.2 \\
\hline & Bare Hands & $0.0 \mathrm{a}$ & $10.3 \mathrm{a}$ & $6.7 \mathrm{a}$ & $3.3 \mathrm{a}$ & 20.8 & 8.0 \\
\hline \multirow[t]{2}{*}{$\begin{array}{l}\text { Means used for } \\
\text { serving salads }\end{array}$} & $\begin{array}{l}\text { Protected } \\
\text { Hands }\end{array}$ & $0.0 \mathrm{a}$ & $3.4 \mathrm{a}$ & $10.0 \mathrm{a}$ & $16.7 \mathrm{a}$ & $0.0 \mathrm{a}$ & 6.5 \\
\hline & Spoon/Ladle & $100 \mathrm{a}$ & $86.2 \mathrm{a}$ & $83.3 \mathrm{a}$ & $80.0 \mathrm{a}$ & $79.2 \mathrm{a}$ & 85.5 \\
\hline
\end{tabular}

Note: Means with the same letter in the same column are not significantly different. $(P<0.05)$. Commun: Yop (Yopougon) and Treich (Treicheville). 
Table 3. Prevalence of bacteria in vegetable salad samples.

\begin{tabular}{cccccc}
\hline \multirow{2}{*}{$\begin{array}{c}\text { Sampling } \\
\text { parameters }\end{array}$} & Categories & $\mathrm{N}$ & \multicolumn{3}{c}{ Prevalence of bacteria (\%) } \\
\cline { 5 - 6 } & To + On & 184 & $100 \mathrm{a}$ & $63.6 \mathrm{a}$ & $0.5 \mathrm{a}$ \\
$\begin{array}{c}\text { Types of vegetables } \\
\text { constituting the } \\
\text { salad }\end{array}$ & To + On $+\mathrm{Cu}$ & 108 & $100 \mathrm{a}$ & $99.1 \mathrm{~b}$ & $5.6 \mathrm{~b}$ \\
& To + On $+\mathrm{Cu}+\mathrm{Lt}$ & 14 & $100 \mathrm{a}$ & $100 \mathrm{~b}$ & $7.1 \mathrm{ab}$ \\
& TOTAL & 306 & 100 & 77.8 & 2.6 \\
$\begin{array}{c}\text { Salads } \\
\text { sampling time }\end{array}$ & Day & 172 & $100 \mathrm{a}$ & $66.9 \mathrm{a}$ & $0.6 \mathrm{a}$ \\
& Night & 132 & $100 \mathrm{a}$ & $91.8 \mathrm{~b}$ & $5.2 \mathrm{~b}$ \\
& TOTAL & 306 & 100 & 77.8 & 2.6 \\
& Abobo & 60 & $100 \mathrm{a}$ & $81.7 \mathrm{a}$ & $5.0 \mathrm{a}$ \\
Communes of & Adjamé & 64 & $100 \mathrm{a}$ & $78.1 \mathrm{a}$ & $3.1 \mathrm{a}$ \\
sampling salad & Treichville & 60 & $100 \mathrm{a}$ & $78.3 \mathrm{a}$ & $3.2 \mathrm{a}$ \\
& Yopougon & 62 & $100 \mathrm{a}$ & $75.8 \mathrm{a}$ & $1.7 \mathrm{a}$ \\
& Cocody & 60 & $100 \mathrm{a}$ & $75.0 \mathrm{a}$ & $0.0 \mathrm{a}$ \\
& TOTAL & 306 & 100 & 77.8 & 2.6 \\
\hline
\end{tabular}

Note: Means with the same letter in the same line are not significantly different $(P<0.05)$. To: tomatoes; On: onion; Cu: cucumbers; Lt: Lettuce.

coli and Salmonella did not vary significantly in vegetable salads collected from one commune to another $(P>0.05)$; on the other hand, they varied considerably according to the sampling time and the type of vegetables making up the vegetable salads $(P<0.05)$. Salads collected at night and salads that contained tomato, onion, cucumber and lettuce showed significantly higher prevalence in $E$. coli and Salmonella $(P<0.05)$.

\subsection{Average Bacterial Loads in Vegetable Salad Samples}

Mean loads of bacteria in the analyzed samples are presented in Table 4. The mean loads were $4.9 \pm 1.1$ and $1.9 \pm 1.3 \log _{10} \mathrm{CFU} / \mathrm{g}$ for Enterobacteriaceae and $E$. coli respectively and were significantly Different $(P<0.05)$. Mean loads of $E$. coli did not vary significantly in samples of vegetable salads taken from one commune to another, unlike those of Enterobacteriaceae. Both varied significantly according the sampling time and type of vegetables comprising the vegetable salad $(P<0.05)$. Salads collected at night and salads containing tomato, onion, cucumber and lettuce showed significantly higher mean $E$. coli loads $(P<$ $0.05)$.

\subsection{Microbiological Quality of Vegetable Salads}

The percentages of unsatisfactory microbiological quality samples are respectively $52.3 \%$ related to E. coli and $2.6 \%$ for Salmonella. Percentages of vegetable salads of unsatisfactory microbiological quality did not vary significantly from samples from one commune to another $(P>0.05)$, but varied significantly according the time of sampling and types of vegetables that made up the salads $(P<$ 0.05). The salads collected at night and salads that contained tomato, onion, 
Table 4. Microbiological quality of samples.

\begin{tabular}{ccccc}
\hline \multirow{2}{*}{$\begin{array}{c}\text { Sampling } \\
\text { parameters }\end{array}$} & Categories & $\mathrm{N}$ & \multicolumn{2}{c}{ Mean load of bacteria $\left(\log _{10} \mathrm{CFU} / \mathrm{g}\right)$} \\
\cline { 4 - 5 } & To + On & 184 & $4.86 \pm 1.1 \mathrm{a}$ & $1.46 \pm 1.3 \mathrm{a}$ \\
$\begin{array}{c}\text { Types of vegetables } \\
\text { constituting the } \\
\text { salad }\end{array}$ & To + On $+\mathrm{Cu}$ & 108 & $4.97 \pm 1.0 \mathrm{~b}$ & $2.54 \pm 1.0 \mathrm{~b}$ \\
& To + On $+\mathrm{Cu}+\mathrm{Lt}$ & 14 & $5.58 \pm 0.9 \mathrm{~b}$ & $2.61 \pm 0.4 \mathrm{~b}$ \\
Tatad & 306 & $4.9 \pm 1.11$ & $1.89 \pm 1.2$ \\
sampling time & Day & 172 & $5.1 \pm 1.1 \mathrm{a}$ & $1.51 \pm 1.31 \mathrm{a}$ \\
& Night & 132 & $4.7 \pm 1.0 \mathrm{~b}$ & $2.39 \pm 1.09 \mathrm{~b}$ \\
& TOTAL & 306 & $4.9 \pm 1.1$ & $1.9 \pm 1.3$ \\
& Abobo & 60 & $5.2 \pm 0.8 \mathrm{a}$ & $2.2 \pm 1.40 \mathrm{a}$ \\
Communes of & Adjamé & 64 & $5.2 \pm 1.2 \mathrm{a}$ & $1.98 \pm 1.3 \mathrm{a}$ \\
sampling salad & Treichville & 60 & $5.0 \pm 1.0 \mathrm{a}$ & $1.85 \pm 1.2 \mathrm{a}$ \\
& Yopougon & 62 & $4.9 \pm 1.1 \mathrm{a}$ & $1.8 \pm 1.3 \mathrm{a}$ \\
& Cocody & 60 & $4.3 \pm 1.2 \mathrm{~b}$ & $1.7 \pm 1.1 \mathrm{a}$ \\
& TOTAL & 306 & $4.9 \pm 1.1 \mathrm{a}$ & $1.9 \pm 1.3 \mathrm{a}$ \\
\hline
\end{tabular}

Note: Means with the same letter in the same line are not significantly different $(P<0.05)$. To: tomatoes; On: onion; Cu: cucumbers; Lt: Lettuce.

cucumber and lettuce presented the most significantly elevated percentages of unsatisfactory microbiological quality $(P<0.05)$ for Salmonella and $E$. coli (Table 5).

\section{Discussion}

The absence of school-level education and training in catering for the majority of vendors are factors that may influence their ignorance of the impact of good handling practices on the quality of food for human consumption [17]. This may explain the lack of precaution, good hygiene practices and proper handling to avoid contamination. According to FAO [18], catering operations posed particular risks (foodborne diseases) because of the way the food is stored and handled. For this purpose, food handlers should be trained in food safety and personal hygiene in order to be aware of the precautions that need to be taken to avoid any form of contamination.

Contamination due to lack of precautions, good handling practices and hygiene measures were observed during the preparation of vegetable salads. It was found that there was absence of effective decontamination of vegetables in order to eliminate or reduce the initial contaminants, the vegetable cutting stage being entrusted to young girls was not always hygienic and the contact of vegetables with foods (chicken, fish, etc.) or utensils that had been in contact with these foods. Contamination was also observed by the preservation of vegetable salads at room temperature during the sale and using bare hands to serve the salads. These factors have already been cited and involved in cases of food contamination in other countries [9] [10] [12] [19] [20] [21] [22]. 
Table 5. Microbiological quality of samples.

\begin{tabular}{|c|c|c|c|c|c|c|c|}
\hline \multirow{3}{*}{$\begin{array}{l}\text { Sampling } \\
\text { parameters }\end{array}$} & \multirow{3}{*}{ Categories } & \multirow{3}{*}{$\mathrm{N}$} & \multicolumn{5}{|c|}{ Microbiological quality of samples (\%) } \\
\hline & & & \multicolumn{3}{|c|}{ E. coli } & \multicolumn{2}{|c|}{ Salmonella } \\
\hline & & & $S$ & $A c$ & $N S$ & $S$ & $C$ \\
\hline \multirow{4}{*}{$\begin{array}{c}\text { Types of vegetables } \\
\text { constituting the } \\
\text { salad }\end{array}$} & To + On & 184 & $36.4 \mathrm{a}$ & $24.5 \mathrm{a}$ & $39.1 \mathrm{a}$ & $99.5 \mathrm{a}$ & $0.5 \mathrm{a}$ \\
\hline & $\mathrm{To}+\mathrm{On}+\mathrm{Cu}$ & 108 & $0.9 \mathrm{~b}$ & $29.6 \mathrm{a}$ & $69.4 \mathrm{~b}$ & $94.4 \mathrm{~b}$ & $5.6 \mathrm{~b}$ \\
\hline & $\mathrm{To}+\mathrm{On}+\mathrm{Cu}+\mathrm{Lt}$ & 14 & $0.0 \mathrm{~b}$ & $7.1 \mathrm{~b}$ & $92.9 \mathrm{~b}$ & $92.9 \mathrm{ab}$ & 7.1ab \\
\hline & TOTAL & 306 & 22.2 & 25.5 & 52.3 & 97.4 & 2.6 \\
\hline \multirow{3}{*}{$\begin{array}{c}\text { Salads } \\
\text { sampling time }\end{array}$} & Day & 172 & $33.1 \mathrm{a}$ & $28.5 \mathrm{a}$ & $38.4 \mathrm{a}$ & $99.4 \mathrm{a}$ & $0.6 \mathrm{a}$ \\
\hline & Night & 132 & $8.2 b$ & $21.6 \mathrm{a}$ & $70.1 \mathrm{~b}$ & $94.8 \mathrm{~b}$ & $5.2 \mathrm{~b}$ \\
\hline & TOTAL & 306 & 22.2 & 25.5 & 52.3 & 97.4 & 2.6 \\
\hline \multirow{6}{*}{$\begin{array}{l}\text { Communes of } \\
\text { sampling salad }\end{array}$} & Abobo & 60 & $18.3 \mathrm{a}$ & $21.7 \mathrm{a}$ & $60.0 \mathrm{a}$ & $95.0 \mathrm{a}$ & $5.0 \mathrm{a}$ \\
\hline & Adjamé & 64 & $21.9 \mathrm{a}$ & $26.6 \mathrm{a}$ & $51.6 \mathrm{a}$ & $96.9 \mathrm{a}$ & $3.1 \mathrm{a}$ \\
\hline & Treichville & 60 & $21.7 \mathrm{a}$ & 28.3 & $50.0 \mathrm{a}$ & $98.3 a$ & $1.7 \mathrm{a}$ \\
\hline & Yopougon & 62 & $24.2 \mathrm{a}$ & $24.2 \mathrm{a}$ & $51.6 \mathrm{a}$ & $96.8 \mathrm{a}$ & $3.2 \mathrm{a}$ \\
\hline & Cocody & 60 & $25.0 \mathrm{a}$ & $26.7 \mathrm{a}$ & $48.3 \mathrm{a}$ & $100.0 \mathrm{a}$ & $0.0 \mathrm{a}$ \\
\hline & TOTAL & 306 & 22.2 & 25.5 & 52.3 & 97.4 & 2.6 \\
\hline
\end{tabular}

Note: Means with the same letter in the same line are not significantly different $(P<0.05)$; To: tomatoes; On: onion; Cu: cucumbers; Lt: Lettuce; Satisfactory: $\mathcal{S}$; acceptable: $A c$, Unsatisfactory: Un; Corrupt: C.

The presence of bacteria with high prevalence and loads in this study could be due to these factors and practices observed during the preparation in collective restoration and which are susceptible to favor this contamination. The raw mixed vegetable salad samples analyzed contained Enterobacteriaceae, E. coli and Salmonellaspp with prevalence and variable average loads. Enterobacteriaceae were found in all samples analyzed with a concentration of $4.9 \pm 1.1 \log _{10}$ $\mathrm{CFU} / \mathrm{g}$. The result obtained is in agreement with that of Mohammed and Bahreini [23] who obtained $100 \%$ prevalence in Iran, but different from those of Nguz et al. [24], who obtained a prevalence of $73.3 \%$. The presence of enterobacteria in raw vegetable salads can be explained by the fact that they are very widespread and widely distributed in the environment via soil, water, intestines of animals and humans, and vegetables. Some enterobacteria are naturally found among the flora associated with growing vegetables [25]. For this reason, the microbiological criteriae for determining the microbiological quality of food are not applicable to fruit and vegetable salads or fresh foods that contain raw fruits and vegetables. According to the health protection agency [26], enterobacteriaare used to assess the general state of hygiene of food products. In thermally untreated products, such as fruits and vegetables, processing methods can reduce the initial load of often very high contamination [26]. Therefore, always having a high load of these types of bacteria in vegetables ready for consumption in the final stage means inadequate treatment [27]. Samples taken during the day had a significantly higher enterobacterial load $\left(5.1 \pm 1.1 \log _{10}\right.$ CFU/g) than the samples collected overnight $\left(4.7 \pm 1.04 \log _{10} \mathrm{CFU} / \mathrm{g}\right)$. This difference could be 
explained by the fact that during the day, raw vegetable salads are used much more as accompaniment of grilled fish. This could be due to cross-contamination during cutting, since the utensils are being used to cut both vegetables and fish. Studies also confirm that fresh fish contain enterobacteria with prevalence up to $100 \%$ and loads of $5.3 \log _{10} \mathrm{CFU} \mathrm{cm} \mathrm{cm}^{2}$ [28] [29].

The prevalence of $E$. coli in our study was $77.8 \%$ with an average concentration of $1.89 \pm 1.29 \log _{10} \mathrm{CFU} / \mathrm{g}$ and $52.3 \%$ of the samples that exceeded the recommended limits. These results are contrary to those of Soncy et al. [30] in Togo and Antwi-Agyei et al. (2015 [31]) in Ghana, which obtained much higher loads of $2.5 \times 10^{3} \mathrm{CFU} / \mathrm{g}\left(3.4 \log _{10} \mathrm{CFU} / \mathrm{g}\right)$ and $4.23 \log _{10} \mathrm{CFU} / \mathrm{g}$, respectively, with a prevalence of $22.8 \%$ and $98 \%$. Similarly, Barrada et al. [32] in Morocco and Amposah et al. [33]) in Ghana had obtained respectively 99.3\% and 100\% raw vegetable salads unsatisfactory microbiological quality. On the other hand, Pesewu et al. [34] in Ghana obtained a load close to our results $\left(1.89 \pm 1.29 \log _{10}\right.$ $\mathrm{CFU} / \mathrm{g}$ ), which is $1.6 \log _{10} \mathrm{CFU} / \mathrm{g}$, but with a lower prevalence (35\%). In Iran, Mohammad et al. [23] and Avazpour et al. [35] obtained 27.8\% and 69\% prevalence respectively with $6.3 \%$ and $69 \%$ of samples of unsatisfactory microbiological quality.

In our study, Salmonella was detected in $2.6 \%$ of the samples. This prevalence is lower than those obtained in India [36] and Harare [37] of 5.8\% and $14 \%$ respectively. However, in Lomé [9], Uganda [38], Iran [35] and Kumasi [10] no Salmonella was detected in the salad samples. All samples analyzed containing Salmonella are unfit for human consumption and pose a risk to consumer health.

The prevalence, average loads and number of samples of unsatisfactory microbiological quality compared to E. coli and Salmonella were significantly higher in salads containing onion, tomato, cucumber and lettuce and in salads collected at night. This could be explained by the number and nature of the vegetables making up the salad and also by the types of meals that are used in accompanying these salads at night. Lettuce, because of its irregular structure, sometimes has a prevalence and average load in larger microorganisms [10]. At night, vegetable salads are much more used as an accompaniment of grilled or braised chicken. Cross-contamination by contact of vegetable salads with fresh chicken or utensils that have been in contact with this food as observed in the survey could be the basis of this situation. The conditions of sale, including personal hygiene, could also be involved. Work carried out by Bony et al. [39] and Koffi et al. [40] have shown that carcasses and fresh products from chickens on the markets of Abidjan are contaminated with strains of E. coli and Salmonella. From one commune to another, there was no significant difference in the prevalence, mean concentration and level of samples of unsatisfactory micro-biological quality compared to $E$. coli and Salmonellaspp $(P>0.05)$. This result suggests in a general way that practices among sellers are the same from one commune to another.

Handling practices in the food service establishment from point of service 
preparation should therefore be a critical concern for food workers and consumers since they can provide great opportunities for cross-contamination of microbes from raw products to ready-to-eat foods [10]. According Amoah et al. [17], unsanitary handling practices after the fields and in the marketing, do not increase the levels of initial contamination; however, the preparation of these foods before consumption in collective catering is the critical stage at which it is absolutely necessary to minimize the microbial load. At this stage, because these foods are consumed without further heat treatment, they require good handling conditions and the use of effective decontamination methods to minimize contamination and thus preserve the health of consumers.

\section{Conclusion}

This study shows that raw mixed vegetable salads consumed in collective catering in Abidjan are contaminated with E. coli and Salmonella. In some cases, average loads are above the limits recommended by WHO and ICMSF to ensure consumer health. Since raw mixed vegetable salads are consumed directly without any treatment, emphasis should be placed on the proper handling conditions of these. Effective decontamination methods such as Sodium hypochlorite should also be used to minimize any form of contamination and to preserve the health of consumers.

\section{References}

[1] Joshipura, K., Ascherio, A., Manson, J., Stampfer, M., Rimm, R., Speizer, F., Hennekens, C., Spiegelman, D. and Willett, W. (2008) Fruit and Vegetable Intake in Relation to Ischemic Stroke. Journal of the American Medical Association, 282, 1233-1239. https://doi.org/10.1001/jama.282.13.1233

[2] OMS, (2004) Améliorer la santé. La stratégie Européenne contre les maladies non transmissibles: Prévention et lutte. Comité régional de l'Europe Cinquante-quatrième session Copenhague, 6-9 septembre 2004 Copenhague, Danemark. http://www.euro.who.int/_data/assets/pdf_file/0007/88198/RC54_fdoc08.pdf?ua=1

[3] Beuchat, L.R. (1998) Surface Decontamination of Fruits Eaten Raw: A Review. Food Safe Issue, ( $\left.\mathrm{N}^{\circ} \mathrm{WHO} / \mathrm{FSF} / \mathrm{FOS} / 98.2\right)$ Food Safe Issue World Health Organization, Genève. $42 \mathrm{p}$. http://apps.who.int/iris/bitstream/10665/64435/1/WHO_FSF_FOS_98.2.pdf

[4] Callejas, T.A., Lopez-Galvez, F., Sbodio, A., Artes, F., Artes-Hernandez, F. and Suslow, T.V. (2012) Chlorine Dioxide and Chlorine Effectiveness to Prevent Escherichia coli 0157:H7 and Salmonella Cross-Contamination on Fresh-Cut Red Chard. Food Contol, 23, 325-332. https://doi.org/10.1016/j.foodcont.2011.07.022

[5] Golberg, D., Kroupitski, Y., Belausov, E, Pinto, R. and Sela, S. (2011) Salmonella typhimurium Internalization Is Variable in Leafy Vegetables and Fresh Herbs. International Journal of Food Microbiology, 145, 250-257. https://doi.org/10.1016/j.ijfoodmicro.2010.12.031

[6] Frank, C., Werber, D., Jakob, P., Cramer, Askar, M., Faber, M., Heiden, M.D., Bernard, H., Fruth, A., Prager, R., Spode, A., Wadl, M., Zoufaly, A., Jordan, S., Kemper, M.J. and Follin, P. (2011) Epidemic Profile of Shiga-Toxin-Producing Escherichia coli O104:H4 Outbreak in Germany. The New England Journal of Medicine, 365, 1771-1780. https://doi.org/10.1056/NEJMoa1106483 
[7] Loncarevic, S., Johannessen, G.S. and Rorvik, L.M. (2005) Bacteriological Quality of Organically Grown Leaf Lettuce in Norway. Letters in Applied Microbiology, 41, 186-189. https://doi.org/10.1111/j.1472-765X.2005.01730.x

[8] European Food Safety Authority (EFSA) (2011) Urgent Advice on the Public Health Risk of Shiga-Toxin Producing Escherichia coli in Fresh Vegetables. EFSA Journal, 9, 2274. https://doi.org/10.2903/j.efsa.2011.2274

[9] Adjrah, Y., Soncy, K., Anani, K., Blewussi, K., Karou, D.S., Ameyapoh, Y., de Souza, C. and Gbeassor, M. (2013) Socio-Economic Profile of Street Food Vendors and Microbiological Quality of Ready-to-Eat Salads in Lomé. International Food Research Journal, 20, 65-70.

[10] Amoah, D.S. (2014) Microbial Risk Assessment of Mixed Vegetable Salads from Selected Canteens in the Kumasi Metropolis. PHD Thesis, Kwame Nkrumah University of Science and Technology, Kumasi, 28 October.

http://ir.knust.edu.gh/bitstream/123456789/7081/1/DOUGLAS\%20AMOAH.pdf

[11] Ensink, J.H.J. (2006) Water Quality and the Risk of Hook-Worm Infection in Pakistani and Indian Sewage Farmers. Ph.D. Thesis, University of London, London, February 2006.

http://www.hygienecentral.org.uk/pdf/jeroen_ensink_thesis_final.PDF

[12] Mensah, P., Yeboah-Manu, D., Owusu-Darko, K. and Ablordey, A. (2002) StreetsFoods in Accra, Ghana: How Safe Are They. Bulletin of the World Health Organization, 80, 546-554.

[13] Wognin, A.S., Ouffoue, K.S., Assemand, E.F., Tano, K. and Koffi-Nevry, R. (2013) Perception des risques sanitaires dans le maraîchage à Abidjan, RCI. International Journal of Biological and Chemical Sciences, 7, 1829-1837. https://doi.org/10.4314/ijbcs.v7i5.4

[14] Nevry, R., Assi-Clair, B.J., Koussemon, M., Wognin, A.S. and Coulibaly, N. (2011) Potential Enterobacteria Risk Factors Associated with Contamination of Lettuce (Lactuca sativa) Grown in the Peri-Urban Area of Abidjan (Côte d'Ivoire). International Journal of Biological and Chemical Sciences, 5, 279-290.

[15] Sackou, K.J., Claon, J.S., Oga, A.S., Aguessi, K.T., Lorougnon, D., Diby, Y. and Kouadio, K.L. (2006) Qualité sanitaire des laitues cultivées à Abidjan. Association Africaine de Microbiologie et d Hygiène Alimentaire, 18, 48-50.

[16] Institut National de la Statistique de Côte d'Ivoire (INS) (2014) Recensement Général de la Population et de l'Habitat 2014 (RGHP 2014): Résultats globaux. http://www.ins.ci/n/RESULTATS\%20GLOBAUX.pdf

[17] Amoah, P., Drechsel, P., Abaidoo, R.C. and Henseler, M. (2007) Irrigated Urban Vegetable Production in Ghana: Microbiological Contamination in Farms and Markets and Associated Consumer Risk Groups. Journal of Water and Health, 5, 455-566. https://doi.org/10.2166/wh.2007.041

[18] Food and Agriculture Organization of the United Nations (2014) Guidance on Hygiene and Safety in the Food Retail Sector. Regional Office for Asia and the Pacific Bangkok, RAP Publication, 1-56.

[19] Uwamere, O.O., Nosa, O.O., Wakil, A.T., Frances, O.N., Eseosa, U. and Nicholas, I.O. (2013) Bacteriological Quality of Vegetable Salads Sold at Restaurants with in Okada Town, Edo State, Nigeria. Journal of Pharmacy and Biological Sciences, 5 , 87-90. https://doi.org/10.9790/3008-0528790

[20] Osamwonyi, O.U, Obayagbona, O.N., Aborishade, W., Olisaka, F., Uwadiae, E. and Igiehon, O.N. (2013) Bacteriological Quality of Vegetable Salads Sold at Restaurants Within Okada Town, Edo State, Nigeria. African Journal of Basic \& Applied Sciences, 5, 37-41. 
[21] Ameko, E., Achio, S., Alhassan, S. and Kassim, A. (2012) Microbial Safety of Raw Mixed-Vegetable Salad Sold as an Accompaniment to Street Vended Cooked Rice in Accra. Ghana African Journal of Biotechnology, 11, 11078-11085. https://doi.org/10.5897/ajb11.2604

[22] Wanyenya, I., Muyanja, C. and Nasinyama, G.W. (2004) Kitchen Practices Used in Handling Broiler Chickens and Survival of Campylobacter spp. on Cutting Surfaces in Kampala, Uganda. Journal of Food Protection, 67, 1957-1960. https://doi.org/10.4315/0362-028X-67.9.1957

[23] Mohammad, B.N.H. and Bahreini, M. (2012) Microbiological Quality of Mixed Fresh-Cut Vegetable Salads and Mixed Ready-to-Eat Fresh Herbs in Mashhad Iran. International Conference on Nutrition and Food Sciences, 39, 62-69.

[24] Nguz, K., Shindano, J., Samapundo, S. and Huyghebaert, A. (2005) Microbiological Evaluation of Fresh-Cut Vegetables Produced in Zambia. Food Control, 16, 623 628. https://doi.org/10.1016/j.foodcont.2004.07.001

[25] Osterblad, M., Pensala, O., Peterzéns, M., Heleniuse, H. and Huovinen, P. (1999) Antimicrobial Susceptibility of Enterobacteriaceae Isolated from Vegetables. Journal of Antimicrobial Chemotherapy, 43, 503-509. https://doi.org/10.1093/jac/43.4.503

[26] Health Protection Agency (2009) Guidelines for Assessing the Microbiological Safety of Ready-to-Eat Foods Placed on the Market.

https://www.gov.uk/government/uploads/system/uploads/attachment_data/file/363 146/Guidelines_for_assessing_the_microbiological_safety_of_ready-to-eat_foods_o n_the_market.pdf

[27] James, J.B. and Ngarmsak, T. (2011) Processing of Fresh Cut Tropical Fruits and Vegetables: A Technical Guide. http://www.fao.org/docrep/014/i1909e/i1909e00.pdf

[28] Eizenberga, I., Terentjeva, M., Valciņa, O., Novoslavskij, A., Strazdiņa, V., Osmjana, J. and Bērziņš, A. (2015) Microbiological Quality of Raw Fish at Retail Market in Latvia. Food Quality and Safety. InNordic View to Sustainable Rural Development, Proceedings of the 25 th NJF Congress, Riga, Latvia, 16-18 June 2015, 342-328.

[29] Elsherief, M.F., Mousa, M.M., El-Galil, H.A. and El-Bahy, E.F. (2014) Enterobacteriaceae Associated with Farm Fish and Retailed Ones. Alexandria Journal of Veterinary Sciences, 42, 99-104. https://doi.org/10.5455/ajvs.153299

[30] Soncy, K., Anani, K., Djeri, B., Adjrah, Y., Eklu, M.M., Karou, D.S., Ameyapoh, Y. and De Souza, C. (2015) Hygienic Quality of Ready-to-Eat Salads Sold in the Street and a Modern Restaurant in Lomé, Togo. International Journal of Biological and Chemical Sciences, 9, 2001-2010. https://doi.org/10.4314/ijbcs.v9i4.24

[31] Antwi-Agyei, P., Cairncross, S., Peasey, A., Price, V., Bruce, J. and Baker, K. (2015) A Farm to Fork Risk Assessment for the Use of Wastewater in Agriculture in Accra, Ghana. PLoS ONE, 10, e0142346. https://doi.org/10.1371/journal.pone.0142346

[32] Berrada, L., El Ouali Lalami, A., Salame, B., Aabouch, M. and Bennani, L. (2016) Assessment of the Microbiological Quality of Salads in the North Central Region of Morocco. International Journal of Innovation and Scientific Research, 25, 510-516.

[33] Amponsah-Doku, F., Obiri-Danso, K., Abaidoo, R.C., Andoh, L.A., Drechsel, P., and Kondrasen F. (2010) Bacterial Contamination of Lettuce and Associated Risk Factors at Production Sites, Markets and Street-Food Restaurants in Urban and Peri-Urban Kumasi, Ghana. Scientific Research and Essay, 5, 217-223.

[34] Pesewu, G.A., Agyei, J.N.Y.K., Gyimah, K.I., Olu-Taiwo, M.A., Osei-Djarbeng, S., Codjoe, F.S., Anim-Baidoo, I., Steele-Dadzie, R. and Ayeh-Kumi, P.F. (2014) Vegetable Salads Prepared and Sold by Street Food Vendors in Korle-Gonno, Accra Metropolis, Ghana. Journal of Health Science, 2, 560-566. 
[35] Avazpour, M., Nejad, M.R., Seifipour, F. and Abdi, J. (2013) Assessment of the Microbiological Safety of Salad Vegetables from Different Restaurants in Ilam. Journal of Paramedical Sciences, 4, 111-115.

[36] Tamkebar, D.H. and Mundhada, R.H. (2006) Bacteriological Quality of Salad Vegetables Sold in Amravati City (India). Journal of Biological, 6, 28-30.

[37] Gadaga, T.H., Samende, B.K., Musuna, C. and Chibanda, D. (2008) The Microbiological Quality of Informally Vended Foods in Harare, Zimbabwe. Food Control, 19, 829-832. https://doi.org/10.1016/j.foodcont.2007.07.016

[38] Mugampoza, D., Byarugaba, G.W.B., Nyonyintono, A. and Nakitto, P. (2013) Occurrence of Escherichia coli and Salmonella spp. in Street-Vended Foods and General Hygienic and Trading Practices in Nakawa Division, Uganda. American Journal of Food Nutrition, 3, 167-175.

[39] Bonny, A.C., Karou, T.G., Ake, M.D.F., Dadie, A.T., Bohoua, L.G. and Niamké, S.L. (2015) Distribution of Serovars and Antibiotic Resistance Genes of Salmonella Isolated from Chicken Gizzards in Abidjan, Côte d'Ivoire. International Journal of Innovation and Applied Studies, 11, 567-578.

[40] Koffi, A.R., Dadie, A., Ouassa, T., Karou, T., Dje, K.M. and Menan, E.I-H. (2014) Serotypes and Antibiotic Resistance of Salmonella spp. Isolated from Poultry Carcass and Raw Gizzard Sold in Markets and Catering in Abidjan, Côte d'Ivoire. International Journal of Current Microbiology and Applied Sciences, 3, 764-772.

\section{Scientific Research Publishing}

\section{Submit or recommend next manuscript to SCIRP and we will provide best service for you:}

Accepting pre-submission inquiries through Email, Facebook, LinkedIn, Twitter, etc. A wide selection of journals (inclusive of 9 subjects, more than 200 journals)

Providing 24-hour high-quality service

User-friendly online submission system

Fair and swift peer-review system

Efficient typesetting and proofreading procedure

Display of the result of downloads and visits, as well as the number of cited articles

Maximum dissemination of your research work

Submit your manuscript at: http://papersubmission.scirp.org/

Or contact aim@scirp.org 